\author{
А. Е. Аникин \\ Институт филологии Сибирского отделения РАН \\ Новосибирск, Россия \\ alexandr_anikin@mail.ru
}

\title{
Из истории русских сибирских диалектизмов: Wetrenoi Kamen
}

Речь идет о выражении, записанном у русских в Якутии академиком Г. Ф. Миллером: Wetrenoi Kamen (Ветреной камень) 'камень, обладающий магическим свойством влиять на погоду’ [Müller, 2003, $117,208]$. Оно называет реалию, о которой русские узнали при контактах с якутами (начиная с XVII в.). По-якутски это sata - 'безоар, или безоаровый камень, находимый в желудке или в печени крупных животных и глухаря; по поверью якутов, этот камень, будучи вынесен на открытый воздух в летний знойный день, производит сильный холодный ветер, бурю, дождь и снег, а зимой тепло', 'изменение погоды с помощью колдовства', 'ветер, вызванный посредством колдовства' [Пекарский, 2, 2122-2123].

По описанию Миллера, при использовании ветреного камня (sata) якуты смачивают его водой или свежей кровью и выкрикивают заклятия, надеясь вызвать тем самым грозу, ветер и дождь или (в жаркий день) холодный ветер и дождь [Müller, 2003, 117]. У русских обитателей низовий Индигирки (индигирщиков) было известно слово сата́ (< якут.) 'камень, осколок метеорита, обладающий, по поверью, магическими свойствами' [Чикачев, 1990, 160].

Якут. sata связано с тюркскими формами типа алт., чагат. и др.jada 'магический камень, силою которого вызывают выпадение и прекращение дождя и снега' и с монгольским материалом (якут. < (?) монг.): п.-монг. 丂̌ada, 亏̌adu, калм. $z a d^{p}$ 'безоар, камень, с помощью которого вызывают дождь'. В тюркских и монгольских языках это, видимо,

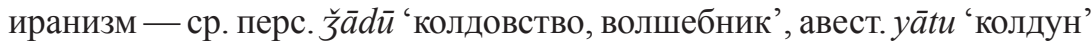
[см.: ЭСРДС, 488-489, с литературой].

Вызывание нужной погоды с помощью магического камня называлось у русских на Индигирке сnускать сату и производилось большей 
частью весной, чтобы снег подмерз и было легко ехать: «Дедушка, крепись, чиво-нибудь да доспей. Сату-ле, чево-ле спусти. Заперлися, не знаем, как до Индигирки добраться» (в рассказе путников, застрявших в дороге из-за оттепели, не чуждый колдовству дедушка сумел вызвать спусканием саты снегопад) [см.: Чикачев, 1990, 132-133]. Колдовство с помощью cambl перенято русскими от якутов [Там же].

Выражение спускать сату передает як. satalā- $(<$ sata + суфф. $-l \bar{a}-)$ 'пускать сату для ненастья, бури' [Пекарский, 2, 2126]. Еще один способ повлиять на погоду у русских обитателей Колымы назывался завязать ветор. Навстречу ветру выставляли женскую одежду. Когда ветер надувал одежду, ее надо было быстро завязать [Богораз, 1901, 53].

У индигирщиков известно также слово погода 'гриб', которое, несомненно, связано с засвидетельствованным на Колыме представлением о том, что срывание грибов влечет непогоду [Богораз, 1901, 109; Чикачев, 1990, 134, 157]. Сорванный гриб выступает как аналог ветреного камня, cambl, способный повлиять на погоду. В различных мифопоэтических традициях известны многочисленные примеры взаимосвязи грибов (их роста) и атмосферных явлений [Топоров, 1979, 254; Белова, 1995, 550].

Белова О. В. Грибы // Славянские древности : этнолингв. словарь : в 5 т. / под общ. ред. Н. И. Толстого. Т. 1. М., 1995. С. 548-551.

Богораз В. Г. Областной словарь колымского русского наречия. СПб., 1901.

Пекарский Э. К. Словарь якутского языка : в 2 т. 2-е изд. Л., 1958-1959.

Топоров В. Н. Семантика мифологических представлений о грибах // Balcanica. Лингвистические исследования / отв. ред. Т. В. Цивьян. М., 1979. С. 234-298.

Чикачев А. Г. Русские на Индигирке. Новосибирск, 1990.

ЭСРДС - Аникин А. Е. Этимологический словарь русских диалектов Сибири. Заимствования из уральских, алтайских и палеоазиатских языков. 2-е изд., доп. М. ; Новосибирск, 2000.

Müller G. F. Nachrichten über Völker Sibiriens (1736-1742) / hrsg. von E. Helimski und H. Katz // Hamburger sibirische und finno-ugrische Materialen. Bd. 2. Hamburg, 2003. 